\title{
RESEARCH OF PLASTICIZERS AND UNSATURATED COMPOUNDS INFLUENCE ON PROPERTIES OF VULCANIZATES SREPT/PVC

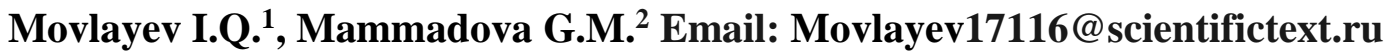

\author{
${ }^{I}$ Movlayev Ibrahim Qumbat oglu - Candidate of Technical Sciences, Associate Professor, \\ DEPARTMENT TECHNOLOGY OF ORGANIC AND HIGHMOLECULAR COMPOUNDS; \\ ${ }^{2}$ Mammadova Gulnura Mustafa qizi - Candidate of Technical Sciences, Associate Professor, \\ DEPARTMENT OF CHEMISTRY AND INORQANIC SUBSTANCE TECHNOLOGY, \\ FACULTY OF CHEMICAL TECHNOLOGY, \\ AZERBAIJAN STATE UNIVERSITY OF OIL AND TECHNOLOGY, \\ BAKU, REPUBLIC OF AZERBAIJAN
}

\begin{abstract}
SREPT) are widely used by production of products, exploited by high temperature and hard conditions.

By aim of improvement of SREPT - 60 properties it have been modificated by compound having the functional group $(P V C)$, leading to it s structural change for good dispersion of PVC in ethylene - propylene rubber and its technological location in composition of rubber on base of SREPT / PVC the linear unsaturated complicated polyesters (MQF - 9, TSE MA) have been added.

For modification of SREPT / PVC composition the more effective unsaturated compounds (MQF - 9, TSMA, $S R N-18-1$ and PAN - CRU - KTP) are used. The properties of vulcanizates (sulphure and peroxide vulcanization) on base of mixture SREPT, having in composition unsaturated compounds have been investigated. On result of these investigation it have been determined that amount of MQF - 9 and TSMA in composition SREPT/PVC (70/30) may be $3 \mathrm{k} / \mathrm{n}$ but by, PVC amount in SREPT/PVC equal (5-10 m. u.) (SREPT/PVC - (95-90/5-10), amount of MQF it is accepted $(0,5-1,0) \mathrm{m} . u$.

Keywords: ethylene-propylene-diene rubber, polyvinyl chloride, oligoesteracryls, plastalloy copolymerization mixture, the degree of cross-linking, zinatullina (CEMA), oligodienes (SKN-18-1, PAN-SKD-KTR).

\section{ИССЛЕДОВАНИЕ ПЛАСТИФИКАТОРОВ И НЕПРЕДЕЛЬНЫХ СОЕДИНЕНИЙ, ВЛИЯЮЩИХ НА СВОЙСТВА ВУЛКАНИЗАТОВ SREPT/PVC Мовлаев И.Г.1, Мамедова Г.М.²}

\footnotetext{
${ }^{1}$ Мовлаев Ибрагим Гумбат огль - кандидат технических наук, дочент, кафедра технологии органических и высокомолекулярных соединений;

${ }^{2}$ Мамедова Гюльнура Мустафа кызы - кандидат технических наук, доцент, кафедра химии и технологии неорганических веществ, химико-технологический факультет,

Азербайджсанский государственный университет нефти и промышленности, г. Баку, Азербайджанская Республика
}

\begin{abstract}
Аннотация: резинь на основе третичного этилен-пропиленового каучука (SREPT) широко используются при производстве изделий, эксплуатируемых при высоких температурах и жестких условиях.

В иелях улучшения свойств SREPT-60 он был модифицирован соединением, имеюшим функциональную группу (ПВХ), что привело кего структурным изменениям для хорошего диспергирования ПВХ в этиленпропиленовом каучуке и его технологическому расположению в составе резины на основе SREPT / PVC добавлены линейные ненасыщенные сложные сложные полиэфиры (MQF-9, TSE MA).

Для модификации композищии SREPT / PVC используются более эффективные ненасыщенные соединения (MQF-9, TSMA, SRN-18-1 и PAN-CRU-KTP). Исследованы свойства вулканизатов (серная и пероксидная вулканизация) на основе смеси SREPT, имеющей в составе ненасыщенные соединения. По результатам этих исследований было установлено, что количество MQF-9 и TSMA в составе SREPT / PVC (70/30) может составлять $3 \kappa$ / н, но по количеству ПВХ в SREPT / PVC равным (5-10 мк) (SREPT / $P V C$ - (95-90 / 5-10), количество MQF принято (0,5 - 1,0) му.

Ключевые слова: этилен-пропилен-диен, каучук, поливинилхлорид, олигоэфиракрилат, сополимеризация пластзольной смеси, степень сиивания, цианэтилметакрилат (ЦЭМА), олигодиенов (СКН -18-1, ПАНСКД-КТР).
\end{abstract}

UDC 66.063.72.677

Rubber, made on base of ethylene-propylene rubber (SREPT), containing fully saturated basic bond, widely is used for manufacture of goods, used in conditions of hard exploitation and high temperatures (up to 140$160^{\circ} \mathrm{C}$ ). On a level with that, use of rubber on base of SREPT, possessing by increased stability to swelling in water and excellent dielectric properties, undoubtedly rouse interest in field production of cables, electrical 
engineering, rubberized cloth, hoses, thermal container tapes, in production of molded and nonmoulded machine parts. Excepting the above-mentioned positive peculiarities, to SREPT inherent also shortages. For example, to wide use of ethylene-propylene rubbers is prevent limited convectional adhesion of its mixtures, low rate vulcanization, low compatibility with another types of rubbers, weak cohesion bond with metal and cloth.

By aim removal of shortages of ethylene-propylene-dien rubber (SKEPT-60), it was subjected to modification by compounds, containing a functional groups (PVC), that allow to made structural change in SREPT-60. For better dispersion of PVC increase of technologically combined arrangement, in rubber mixture on base of SREPT/PVC the liquid unsaturated compounds (MQF-9, TSMA) are introduced.

The interest to oligoesteracrylatis (OEA) in determined by that it by vulcanization are connected to rubber and give to rubber a series of technically voluable specific properties. The line OEA (MQF-9) unlike from ester plasticizers by DBF type badly are combined with elastomers. The balanced solubility of OEA in rubbers depend both from rubber polarity and molecular mass and chemical structure of OEA. All OEA improve a technological properties of rubber mixtures, moreover by use of line tetrafunctional olyqomers decrease of viscosity is more than in case of polyfunctional [1].

The effects of wetting of polar surfaces, distinctive for OEA and strengthening interaction between them and unipolar rubbers have a special significance by making of rubbers, fueled by high polar thermoplastic polymerpolyvinylchloride.

Addition of PVC give to rubber a useful technical properties such as chemical stability in different mediums, good electrical properties, ozonestability, uncombustibility, high mechanical strength and harness.

By introduction of PVC in rubber mixtures on base of nonpolar rubbers (SREPT) there is not observed of noticeable strengthening of vulcanizates, although a complex rubber properties in whole is improved.

The most effect is achieved by introduction of polymer fillers with olygomers in state of as a preliminary prepared composition of determined composition (plastisols).

Combination of physical- chemical properties indices with good technological properties of robber mixtures increase possibility making of the new rubber cloth with special properties [2].

In connection with that influence of olygoesteracrylates on physical-mechanical properties of vulcanizes mixture SREPT/PVC is researched.

From showed on illustration 1dates one can see that by sulphuric vulcanization of the mixture SREPT/PVC increase of MQF content more than $3 \div 5$ p.mas. lead to deterioration of vulcanized properties. By peroxide vulcanization, the wrong way a sharp increase of strength properties is occur and also content of sol fraction is decreased.

Improvement of vulcanized SREPT/PVC properties by introduction of OEA more clearly is traced by peroxide vulcanization, that is explained by decrease of viscosity of rubber mixtures by introduction of MQF-9 and proceeding of reaction copolymerization of MQF-9 and rubber in vulcanization process (Figure 1).

Degree of uninitiated polymerization of MQF-9 in mixtures with rubbers by $432 \mathrm{~K}$ maxes up $15-60 \%$. At the same time joint of rubber is occur and content of sol fraction reach 30-50\%. Introduction of initiators radical polymerization, for example peroxide increase a degree joint of vulcanizates and improve of its properties [3].

By vulcanization of plastisol mixture PVC/MQF-9 by correlation PVC: MQF-9 2:1 with 0,5 p.mas Maximum Permissible Concentration (MPC) a strength increased by tension of these vulcanizates about in 2 time $(38,4$ compared with $19,1 \mathrm{MPa})$ and by sulphuric vulcanization of analogous mixture strength by tension of vulcanizates is within 8-9 MPa.

By use of combinated vulcanizing systems for vulcanization of rubbers on base of SREP/PVC, containing MQF-9 (LAK-2,0; sulphur-1,4; thiuram-1,05; captax-0,5 p.mas) conditional strength by tension vulcanizates made up $11,9 \mathrm{~Pa}$ that is lower than by vulcanizates of these mixtures, received by clearly sulphur vulcanization. It is explained by inhibitoring action of sulphur on radical polymerization MQF-9 [2, 4]. In connection with that use of MPC in combination with sulphur containing vulcanizating system is inexpedient.

For choice of the most effective olygomers formodification of mixtures SREP/PVC by use the properties of rubbers, containing OEA-MQF, TQM-3, Content of OEA-MQF-9, p.mas. 


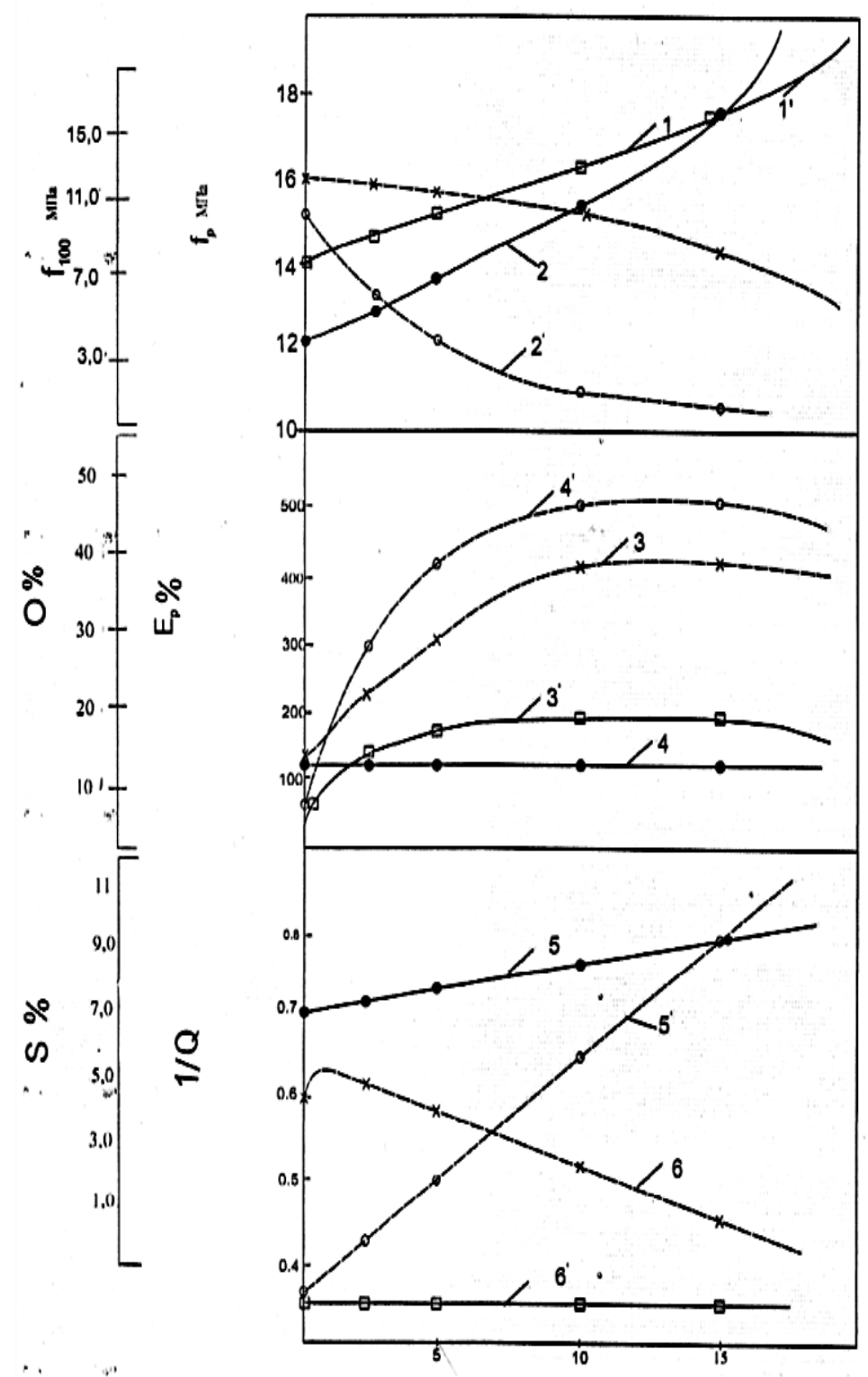

Fig. 1. Influence of MQF-9 content on properties of vulcanizates of mixtures SREPT/PVC.

Conditional strength by tense $\operatorname{Sp}(1,2)$ Conditional voltage by extension $100 \%, f_{p}(1,2)$, relative extension $E_{p}(3,4)$, residual deformation $O(3,4)$, joint degree $1 / Q(5,6)$, content of sol-fraction $S(5,6)$. Vulcanization: .......(sulphuric $443 \mathrm{~K}, 30$ minutes)___(peroxide $443 \mathrm{k}, 30$ minutes)

Cynethylmetaclylate (CEMA) have been studied, which were used before for improvement of properties rubbers on base of combinations SRMS-30ARX with PVC [2]. As one can see from showen on Figure 1 date, MQF-9 ensure the best complex properties of vulcanizates of mixture SREPT/PVC than TQM-3. The reason of obrerd improvement properties of rubbers, containing MQF-9 in comparison with TQM-3 is the best compatibility of MQF-9 with mixture SREPT/PVC [4, 5].

By use of CEMA a total regularities, observed by use of MQF-9 are preserved. By peroxide vulcanization strength of vulcanizates containing up to 5p.mas of CEMA don't differ from strength of vulcanizates without CEMA (Figure 2).

Increase content of CEMA in mixtures SREPT/PVC in amount more 5p.mas. lead to improvement of such properties of vulcamizates of these mixtures as strength by tension and conditional voltage by extension $100 \%$. By sulphuric vulcanization of pointed mixtures, containing more 5p.max of CEMA the physical-mechanical properties of vulcanizates are worsening (Figure 2).

Influence of temperature maxing on properties of sulphuric vulcanizates of mixture SREPT/PVC (70/30) p.mas in presence of different plasticizers (15 p.mas.) have been studded. It was showen (Figure 3) that increase of temperature mixing lead to improvement interaction between polymer components of mixture, but a significant effect change of physical-mechanical properties of vulcanizates of these mixtures in not observed (Figure 3). 
Moreover, by that method preparation of rubber mixtures TQM-3 also less effectively influence on properties of vulcanizates than MQF-9, that is explained by compatilility of NQF-9 with SREPT [5].

By peroxide vulcanization of mixture SREPT/PVC (PDK-3p.mas.) by increase of olygodines amount (SRN18-1,PAN-SRD-KTP) strength by extension (16 compare with $12,5 \mathrm{MPa})$, joint degree (0,80 compare with $0,21)$, content of sol-fraction (1,4 compare with $0,98 \%)$ and hardness of vulcanizates are increased.

Relative extension of vulcanizates is decreased from $125 \%$ up to $95 \%$. By sulphuric vulcanization of SREPT/PVC introduction of SRN-18-1 and PAN-SRD-KTR in mixture lead to sharp deteriozation of the all pointed physical-mechanical properties of vulcanizates, that is explained by inhibition of sulphuric vulcanization by these olygodiens, therefore these olygodiens don't recommended for use in these mixtures use of PVC by olygodiens (SRK-18-1;PAN-SRD-KTP), containing a functional groups, lead to improvement of oil-and frostresistance of rubbers.
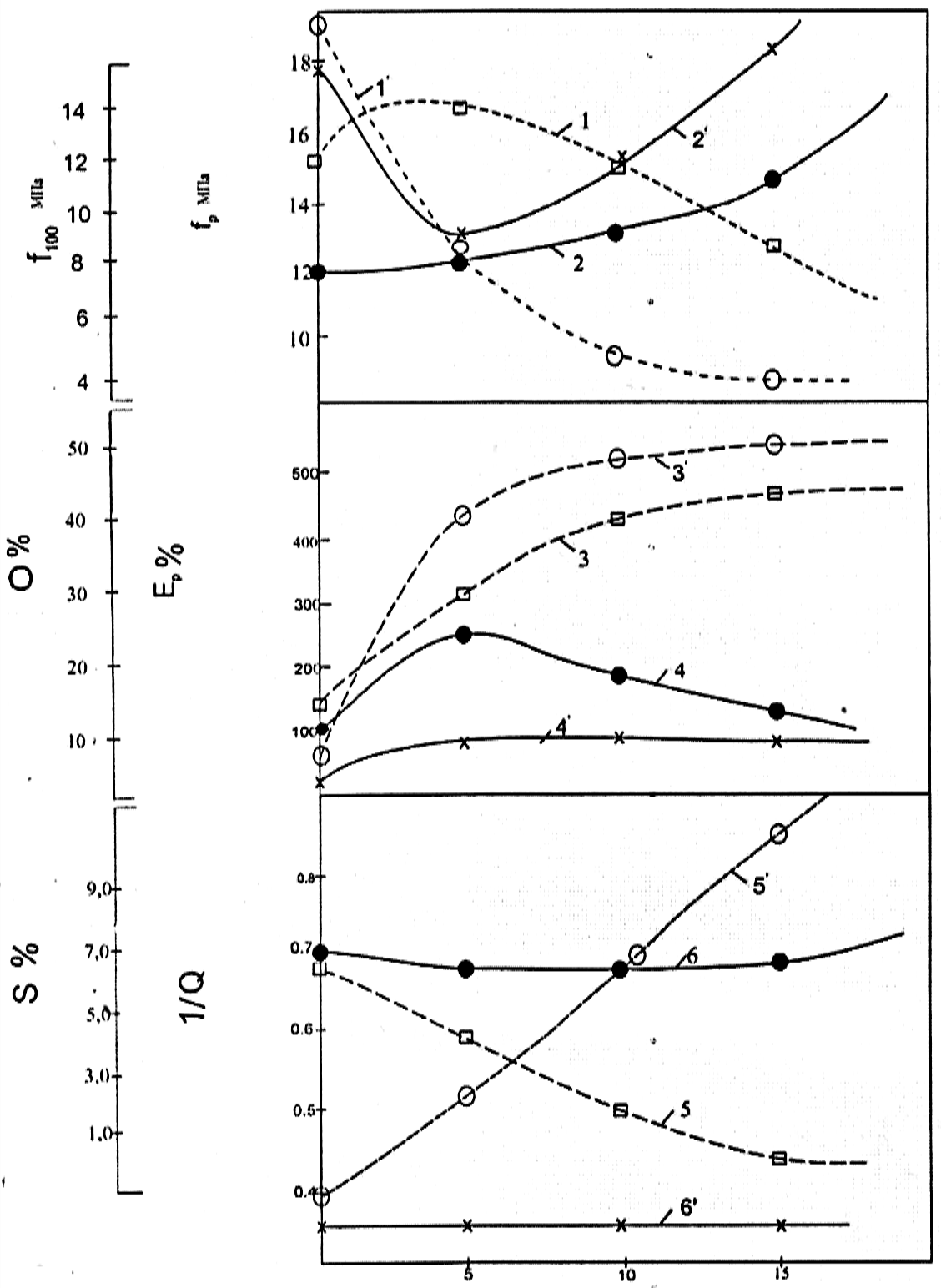

Fig. 2. Influence of CEMA content on properties of vulcanizaty of mixtures SREPT/PVC.

Conditional strength by tension $f_{p}(1,2)$, conditional voltage by extension $100 \% f_{p}\left(1^{\prime}, 2^{\prime}\right)$, relative extension $E_{p}(3,4)$, relative residual deformation $O(3 /, 4 /)$,joint degreem $1 / Q(5,6)$, content of sol fraction $S(5,6)$. Vulcanization:....(silphuric $443 k, 30$ minutes-(peroxide $443 \mathrm{~K}, 30$ minutes) 


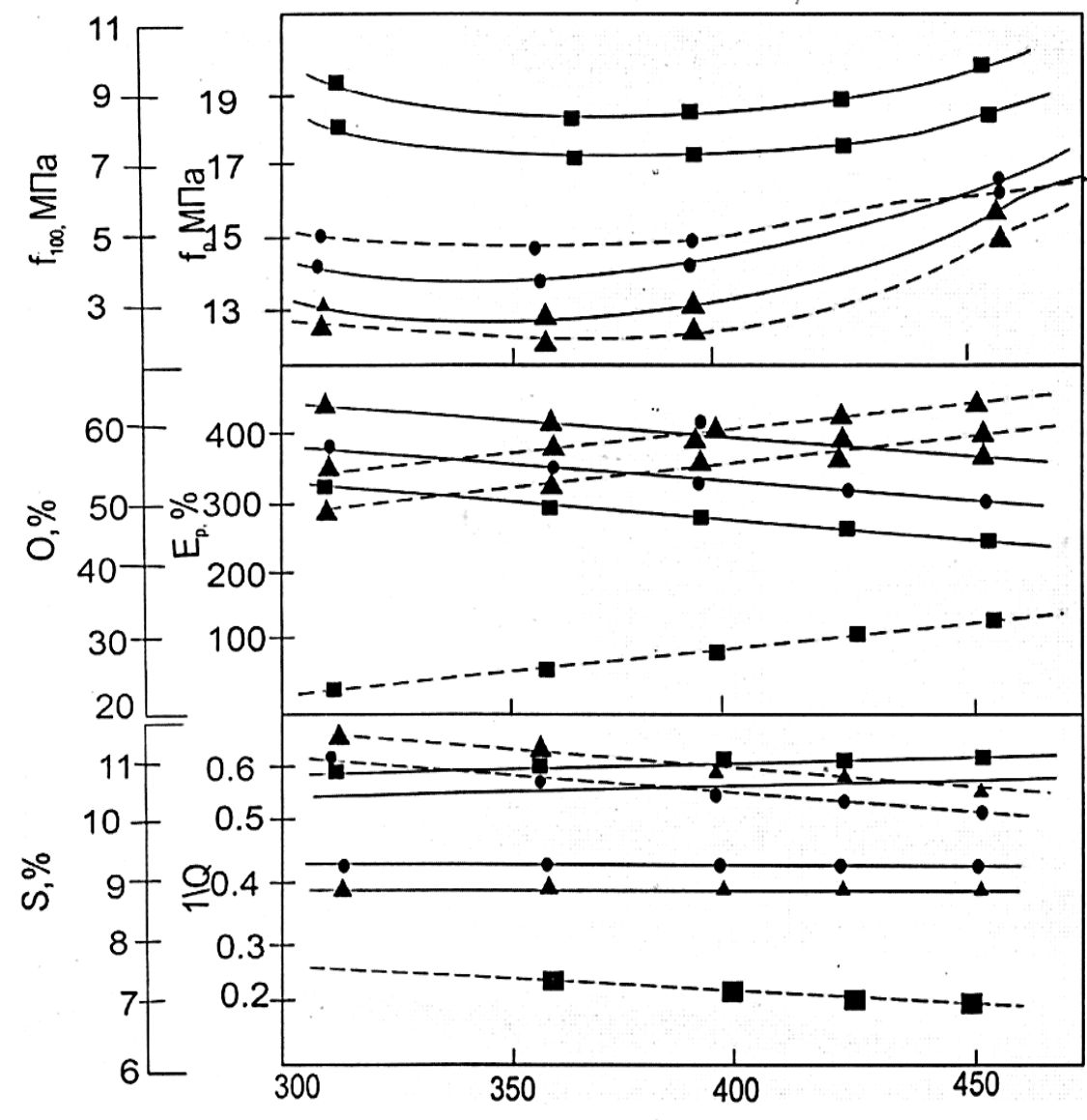

Fig. 3. Influence of mixing temperature on properties of vulcanizates of mixtures SREPT/PVC.

Conditional strength by tension $f_{p}(1,2,3)$, conditional voltage by extension $100 \%, f_{100}\left(1^{/ / 2} / 3^{/}\right)$, relative extension $E_{p}(4,5$,

6), relative residual deformation $O\left(4^{/}, 5^{/}, 6^{/}\right)$joint degree $1 / Q(7,8,9)$, content of sol fraction $\left(7^{/}, 8^{/}, 9^{/}\right)$. Content of plasticizers (15 p.mas) CEMA.

$\triangle-T Q M-3 ; \bullet M Q F-9$

Vulcanization- $443 \mathrm{~K}, 30$ minutes

Temperature of mixing, $\mathrm{K}$

Taking into consideration, that in more elastic rubbers a small amount of (PVC) nill be used, an influence of high mentioned unsaturated compound (plasticizers) on properties of vulcanizates mixtures SREPT/PVC, containing (5-10) p.mas. PVC was researched. Properties of vulcanizates mixtures, containing a small amount of vulcanizates mixtures, containing a small amount of MQF-9 are given in table 1.

Table 1. Influence of plasticizers on physical-mechanical properties of vulcanizates mixtures SREPT/PVC

\begin{tabular}{|c|c|c|c|c|c|}
\hline & \multicolumn{5}{|c|}{ Composition of mixtures } \\
\hline $\mathbf{1}$ & $\mathbf{2}$ & $\mathbf{3}$ & $\mathbf{4}$ & $\mathbf{5}$ & $\mathbf{6}$ \\
\hline SREPT-60 & 100 & 95 & 95 & 90 & 90 \\
\hline PVC E-62 & - & 5 & 5 & 10 & 10 \\
\hline MQF-9 & - & - & 0,5 & - & 1,0 \\
\hline
\end{tabular}

Table 2. Properties of vulcanizates

\begin{tabular}{|c|c|c|c|c|c|c|}
\hline & 1 & 2 & 3 & 4 & 5 & 6 \\
\hline 1 & Conditional strength by extension, MPa & 20,7 & 21,4 & 21,2 & 20,8 & 20,1 \\
\hline 2 & Conditional voltage by lengthening 100\%,MPa & 3,6 & 3,8 & 3,6 & 3,9 & 3,1 \\
\hline 3 & Conditional voltage by lengthening 300\%,MPa & 13,6 & 14,3 & 14,0 & 15,6 & 14 \\
\hline 4 & Relative lengtheming, $\%$ & 380 & 385 & 400 & 370 & 385 \\
\hline 5 & Relative residual deformation, $\%$ & 14 & 16 & 18 & 20,5 & 21,5 \\
\hline
\end{tabular}




\begin{tabular}{|c|c|c|c|c|c|c|}
\hline 6 & Resistance to parting,kH/m & 32,9 & 34 & 38 & 38 & 43,1 \\
\hline 7 & Elasticity on recoil ,\% & 40 & 40,5 & 42 & 40 & 41 \\
\hline 8 & Hrdness by TM-2, cond.un. & 70 & 70 & 68 & 71 & 69 \\
\hline 9 & Strength of connection with metal,Mpa & 1,45 & 1,78 & 1,95 & 1,95 & 2,8 \\
\hline 10 & $\begin{array}{c}\text { Weary durability by repeated } \\
\text { tension }(\varepsilon=200 ; \mathrm{V}=250 \text { cycle/minute } \mathrm{T}=293 \mathrm{~K}) \text {, cycles }\end{array}$ & 1150 & 1360 & 2850 & 1110 & 1990 \\
\hline 11 & 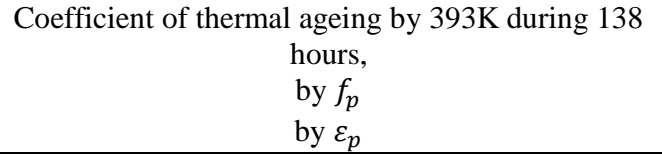 & $\begin{array}{l}0,76 \\
0,41\end{array}$ & $\begin{array}{l}0,79 \\
0,40\end{array}$ & $\begin{array}{l}0,80 \\
0,45\end{array}$ & $\begin{array}{l}0,85 \\
0,39\end{array}$ & $\begin{array}{l}0,84 \\
0,42\end{array}$ \\
\hline 12 & $\begin{array}{l}\text { Fire-resistance, } \\
\text { time of damping } \\
\text { time of smouldening }\end{array}$ & $\begin{array}{c}292 * \\
9\end{array}$ & $\begin{array}{c}358^{*} \\
9\end{array}$ & $\begin{array}{c}365^{*} \\
9\end{array}$ & $\begin{array}{c}67 \\
8 \\
\end{array}$ & $\begin{array}{c}70 \\
8\end{array}$ \\
\hline 13 & $\begin{array}{c}\text { Degree of swelling during } 120 \text { hours, } \% \\
\text { in gasoline } \\
\text { in gasoline-benzene }(3: 1)\end{array}$ & $\begin{array}{c}120,5 \\
147\end{array}$ & $\begin{array}{l}108,1 \\
136,9\end{array}$ & $\begin{array}{c}110,3 \\
138\end{array}$ & $\begin{array}{c}99,0 \\
126,5\end{array}$ & $\begin{array}{c}100 \\
128,1\end{array}$ \\
\hline
\end{tabular}

Analysis of data, showen in table 1 testify about that addition in composition on base of mixture in correlation SREPT-60/PVC-90-95/10-5, 1-2 p.mas. of saturated plasticizer lead to improvement of their physical lead to improvement of their physical-chemical properties compare with compositions on base of SREPT-60. Thus, on base of research results of influence of different plasticizers on physical-mechanical properties of vulcanizates SREPT/PVC (70/30) the expediency use in mixtures SREPT/PVC of unsaturated plasticizers CEMA (5-10 p.mas.) and MQF-9 (up to 3 p.mas.) is recommended.

Analogical improvement of properties show that given saturated plasticizey contribute to good dispersion and steady distribution of PVC in composition on base of mixture SREPT-60/PVC.

\section{References / Сиисок литературы}

1. Huseynov F.I., Bilalov Y.M. Modificated polymer composition Baku, 2000. 214 p.

2. Dontsov A.A., Kanauzova A.A., Litvinova T.V. Rubber- oligomer compositions in production of rubber goods. M. Chemistry, 1986. 216 p.

3. Kuzminskiy A.S., Kavun S.M., Kirpichev Y.P. Physical-Chemical bases of production, processing and use of elastomers-M,Chemistry, 1976. P. 26-28.

4. Dontsov A.A. Processes of elastomers structuriziation. M.: Chemistry, 1978. 287 p.

5. Panchenko V.I., Frenkel R.Sh., Berlin A.A., Lopasteyskiy S.N. Determination of compatibility of olygoesteracrylates with rubbers of different polarity/ functional organic compounds and polymers. Volgograd, 1975. P. 214-215. 